\title{
The Development of Diagnosis for Atopic Dermatitis by Evaluating the Expression of Skin Barrier Proteins Using a Non-Invasive Method
}

\author{
In Sik Kim ${ }^{1,2}$, Ji-Sook Lee ${ }^{3}$ \\ ${ }^{1}$ Department of Biomedical Laboratory Science, School of Medicine, Eulji University, Daejeon, Korea \\ ${ }^{2}$ Department of Senior Healthcare, BK21 Plus Program, Graduate School, Eulji University, Daejeon, Korea \\ ${ }^{3}$ Department of Clinical Laboratory Science, Wonkwang Health Science University, Iksan, Korea
}

\section{비침습적 피부장벽단백질 측정을 통한 아토피 피부염의 진단 및 유용성}

김인식 ${ }^{1,2}$, 이지숙 ${ }^{3}$

${ }^{1}$ 을지대학교 대전캠퍼스 임상병리학과, ${ }^{2}$ 을지대학교 대전캠퍼스 BK21 플러스 프로그램 시니어 헬스케어학과, ${ }^{3}$ 원광보건대학교 임상병리과

\begin{abstract}
Atopic dermatitis is a chronic inflammatory skin disease caused by a variety of genetic and environmental factors, dysregulation of immunological response, as well as dysfunction of the skin barrier proteins. The purpose of this study is to develop an ELISA kit suitable for evaluating the expression of skin barrier proteins. Proteins were obtained from the skin via AriNo and D-Squame patches. The efficiency of protein collection from the skin, using the Arino patch, was shown to be more effective than using D-Squame; while the efficiency of lysis using $0.1 \%$ Triton-X100 was higher than that of other lysis solutions, including $0.1 \mathrm{M}$ Tris-HCL, $0.1 \%$ Tween-20, and $5 \mathrm{mM} \mathrm{KOH}$. Recombinant skin barrier proteins, such as filaggrin and involucrin, were produced by molecular biological methods. Monoclonal antibodies against filaggrin and involucrin were produced by immunization of mice, fusion of spleen cells and myeloma cells, as well as a selection of antibody-producing hybridoma cells. The filaggrin expression in the skin of subjects suffering from atopic dermatitis was lower than that in normal mice. Involucrin expression was not altered between normal individuals and subjects with atopic dermatitis. These findings contribute to an elucidation of the importance of the skin barrier protein expression in atopic dermatitis and the development of a diagnostic kit for atopic dermatitis.
\end{abstract}

Key words: Atopic dermatitis, Skin barrier protein, Filaggrin, Diagnosis

This is an Open Access article distributed under the terms of the Creative Commons Attribution Non-Commercial License (http://creativecommons.org/licenses/by-nc/4.0) which permits unrestricted non-commercial use, distribution, and reproduction in any medium, provided the original work is properly cited.

Copyright @ 2017 The Korean Society for Clinical Laboratory Science. All rights reserved.

\author{
Corresponding author: Ji-Sook Lee \\ Department of Clinical Laboratory Science, \\ Wonkwang Health Science University, 501 \\ Iksandae-ro, Iksan 54538, Korea \\ Tel: 82-63-840-1216 \\ Fax: 82-63-840-1219 \\ E-mail: jslee1216@wu.ac.kr
}

Received: October 11, 2017

Revised $1^{\text {st: }}$ October 25, 2017

Revised $2^{\text {nd }}$ : October 30, 2017

Revised $3^{\text {rd }}$ : October 31, 2017

Accepted: October 31, 2017

\section{서 론}

아토피 피부염은 피부에서 일어나는 알러지 질환이다[1-4]. 아토피 피부염의 증상으로는 만성적인 피부의 가려움증, 염증, 세균감염이 있다. 아토피 피부염은 국내 및 전세계적으로 꾸준
히 증가하는 추세에 있으며, 성인이 되면서 알러지 비염 및 천식 으로의 이행이 나타나기도 한다. 아토피 피부염의 원인으로는 알러지 반응을 일으키는 집먼지 진드기, 꽃가루와 같은 알러젠 과 미세먼지, 공기오염과 같은 환경적인 요소들이 알려져있다. 개체에 따라 다르게 나타나는 면역세포 및 $\mathrm{IgE}$ 의 반응을 포함하 
는 면역학적인 작용기전과 다양한 유전적인 요소도 중요한 원 인인자이다. 하지만, 아직까지 정확한 아토피 피부염의 원인 및 치료방법은 알려져 있지 않다.

피부장벽단백질은 피부구조를 이루고 있는 중요한 요소로 서, 외부 항원이 체내 안으로의 유입되는 것을 차단하는 중요한 역할을 한다[5]. 피부장벽단백질의 종류로는 필라그린 (filaggrin), 인보루크린(involucrin), 로리크린(loricrin)이 있 다. 피부장벽단백질의 유전적인 요소와 발현의 변화는 아토피 피부염을 일으킬 수 있다는 연구결과가 최근에 발표되면서 피 부장벽 단백질의 중요성에 관심이 집중되고 있다. 피부장벽단 백질의 유전적 다형성의 존재와 아토피 피부염의 연관성이 알 려져 있고, 피부장벽단백질 발현의 감소는 아토피 피부염을 악 화시킬 수 있다는 내용이다[6,7].

본 연구는 아토피 피부염에서 피부장벽단백질의 중요성을 규명하고, 비침습적인 방법을 이용한 피부장벽단백질의 채취 및 발현 변화를 진단하는 방법의 개발에 있다.

\section{재료 및 방법}

\section{1. 피부샘플에서의 단백질 추출}

화상용 피부보호로 사용하는 AriNo (Duksung, Daegu, Korea)와피부검사에 가장 많이 사용하는 D-Squame (CuDerm, Dallas, TX, USA)을 손목 또는 팔꿈치 안쪽에 부착시킨 후 먼지 및 피부 부유물을 제거하였다. 다시 다른 패치를 부착시키고, 일 정한 힘을 가하여 1 분 후에 패치를 떼어내어 실험 전 까지 실온 또는 냉장 보관하였다. 용해액 0.1 M Tris-HCL, 0.1\% Tween $20,5 \mathrm{mM} \mathrm{KOH}, 0.1 \%$ Triton-X100 $10 \mathrm{~mL}$ 로 각각 패치를 용 해시킨다. 용해액의 단백질을 농축시키기 위하여 농축 column Amicon Ultra-4 Centrifugal Filter Unit with Ultracel-3 membrane (EMD Millipore,billerica, MA, USA)을 사용하고, Lowry 방법을 이용하여 단백질을 정량하였다.

\section{2. 피부장벽단백질의 재조합 단백질 생산}

피부각질세포인 $\mathrm{HaCaT}$ 세포에서 RNA를 Trizol (Thermo Fisher Scientific, Carlsbad, CA, USA)로 추출한 후에 iScript
cDNA kit (BIO-RAD, San Francisco, CA, USA)를 이용하여 $\mathrm{CDNA}$ 를 만들었다. Table 1의 프라이머를 사용하여 PCR을 진 행하였고, pET28 발현벡터(Merck Millipore, Darmstadt, Germany)에 클로닝을 하였다. 벡터를 BL21 (DE3, Merck Millipore) 대장균에 형질전환시키고, $1 \mathrm{mM}$ isopropyl $\beta$-D-thiogalactoside (Sigma Korea, Seoul, Korea)을 넣고, $37^{\circ} \mathrm{C}$ 에서 16 시간 동안 단백질을 발현시킨다. 대장균을 원심분 리한 후에 BugBuster Protein Extraction reagent (Merck Millipore)을 이용하여 단백질을 추출하였다. 최종적으로 발현 된 재조합 단백질을 nickel column을 이용하여 분리하였다.

\section{3. 항체 생산}

면역 전에 생후 6주령의 Balb/c 마우스(Orient, Seongnam, Korea)의 피를 안와채혈로 채취하고, 준비된 재조합 인보루크 린과 필라그린 단백질 $(50 \mu \mathrm{g})$ 에 같은 부피의 프로이드 완전 아 쥬번트(Freund's complete adjuvant) (Sigma Korea)에 혼합 하여 현탁액을 만든 후, 현탁액 $200 \mu \mathrm{L}$ 를 마우스에 복강 투여하 여 면역시킨다. 첫 번째 면역한 날부터 14일 후 2차 면역하고, 14 일 후 3 차 면역하고 7 일 후 안와 채혈한 혈청은 10,000 배 희 석한 혈청에서도 각 단백질에 대한 항체역가가 모두 OD 450 $\mathrm{nm}$ 에서 1.0 이상의 결과가 나와 비장에서 적출한 세포와 $\mathrm{SP} 2 / 0$ (ATCC) 세포융합을 실시하였다. 융합이 된 세포를 선택 하기 위하여 HAT 배지를 사용하였고, 집락이 형성된 세포를 회 수하여 배양하였다. 항체생산을 확인하기 위하여 세포 상층액 으로 ELISA를 실시하였다.

\section{4. 웨스턴 블럿팅}

재조합단백질을 SDS-polyacrylamide 젤 전기영동한 후에 단백질을 nitrocellulose막으로 이전시켰다. 생산한 항체를 각 각 처리한 후 실온에서 2시간 반응시켰다. 3 번 세척한 후에 2차 항체(secondary anti-mouse $\mathrm{Ab}$ )와 반응시켰고, 3번 세척하였 다. Enhanced chemiluminescence detection system (Amersham Pharmacia Biotech)을 이용하여 필름에 인화하 였다.

Table 1. Primer sequences of filaggrin and involucrin

\begin{tabular}{ccc}
\hline Target gene & Primer & Accession number \\
\hline Filaggrin & $F: 5^{\prime}$-ttccatatg catgaacagtctgagtccgc-3' & NM_002016.1 \\
Involucrin & $R: 5^{\prime}-$ ccgctcgag ttaagatcctgaatgtccagacg-3 & NM_005547.2 \\
& R : 5'-ttccatatg atgtccagcaacacacact-3' & N'-ccgctcgagttatagctgctgatccctttgtg -3' \\
\hline
\end{tabular}




\section{Sandwich ELISA}

필라그린과 인보루크린 항체를 각각 96 well 플레이트에 $4^{\circ} \mathrm{C}$ 에서 코팅한 후에 피부에서 얻은 단백질 추출물을 넣고, 2 시간 동안 실온에서 반응시켰다. 다시 각각의 항체를 2 시간 동 안 실온에서 반응시켰다. 2차horse raddish peroxidase (HRP) 가 붙어 있는 마우스에 대한 항체를 넣는다. 발색 substrate를 넣고 실온에서 반응시킨 후 분광광도계로 측정하였다.

\section{6. 실험 대상군}

을지대학교 재학생 중 정상인과 아토피 피부염으로 병원에 서 진단받은 환자 각각 10 명을 대상으로 피부장벽단백질의 양 을 측정하였다. 본 연구는 을지대학교 임상윤리시험위원회 의 심의를 인준받아서 진행하였다(EU-14-33) (2014년9월부터 2017년7월까지) 참여한 모든 대상자에게 연구의 목적, 연구방 법, 내용을 설명하고, 개인정보와 비밀보장에 대한 내용을 공지 하였고, 연구참여동의서를 받았다.

\section{7. 통계 분석}

결과 값은 '평균ㅍ표준편차’로 제시하였고, 2 개의 대상군 통 계는 paired $t$-test로 PASW Statistics version 18.0 (SPSS, Chicago, USA)로 분석하였다.

\section{결 과}

\section{1. 비침습적 패치를 이용한 피부단백질의 채취}

피부에서의 단백질 채취는 침습적인 생검이 이루어진다. 본 연구에서는 비침습적으로 피부장벽단백질을 측정하기 위해서 먼저 패치를 통한 단백질을 얻을 수 있는지 알아보았다. 화상용 패치로 쓰이는 AriNo 패치와 연구용으로 보편적으로 단백질 채 취에 사용하는 D-Squame은 비교 실험하였다. Arino패치가 D-Squame보다 2배정도 높은 단백질 획득율을 나타냈다 (Figure 1A). Arino패치와 D-Squame를 크기 별로 해보았을 때, $1.69 \mathrm{~cm}^{2}(1.3 \mathrm{~cm} \times 1.3 \mathrm{~cm})$ 보다는 $25 \mathrm{~cm}^{2}(5 \mathrm{~cm} \times 5 \mathrm{~cm})$ 를 사 용하였을 때, 약 2 4 배, 높게 나타났다(Figure 1B). 또한 단백질 용해용액의 종류도 단백질 획득에 영향을 주었다. 일반 용해용액인 0.1 M Tris-HCL용액을 이용하여 얻은 단백질의 양 을 $100 \%$ 로 보았을 때, $5 \mathrm{mM} \mathrm{KOH}$ 용액은 유사하게 나타났고, $0.1 \%$ Tween-20용액은 1.5 배, $0.1 \%$ Triton X-100용액이 2배 높게 나타났다(Figure 1C). 단백질의 채취하는 위치는 앞서 채 취한 부위인 팔꿈치의 안쪽 접히는 부위가 손목보다 피부단백 질의 획득율이 높게 나타났다(Figure 1D).

\section{2. 피부단백질의 재조합단백질 및 항체 생산}

필라그린, 인보루크린, 로리크린과 같은 피부장벽단백질을 생산하기 위하여 먼저 세포에서 RNA추출하고, $\mathrm{CDNA}$ 를 만들 었고(Figure 2A), pET28 발현 벡터에 클로닝하였다. 그 이후 재 조합단백질을 생산하였다. 필라그린과 인보루크린은 재조합단
A

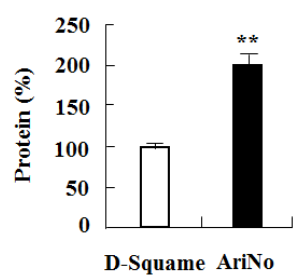

C

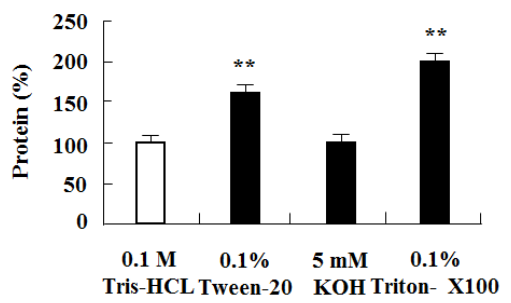

B

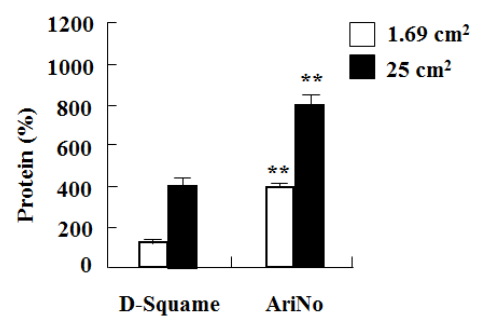

D

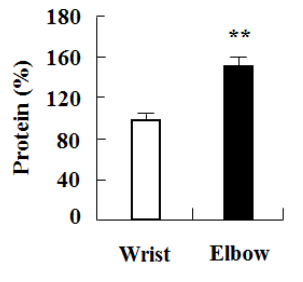

Figure 1. Efficacy of AriNo patch for collection of protein from skin. (A) Comparison of the AriNO patch with D-Squame applied for protein collection. (B) Comparison of protein collection depending on patch size. (C) Comparison of the indicated lysis solutions during protein collection. (D) Comparison of protein collection from the wrist and elbow. 
A

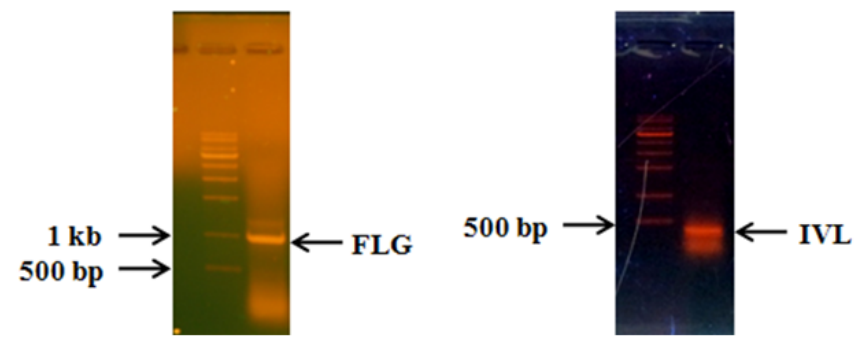

B

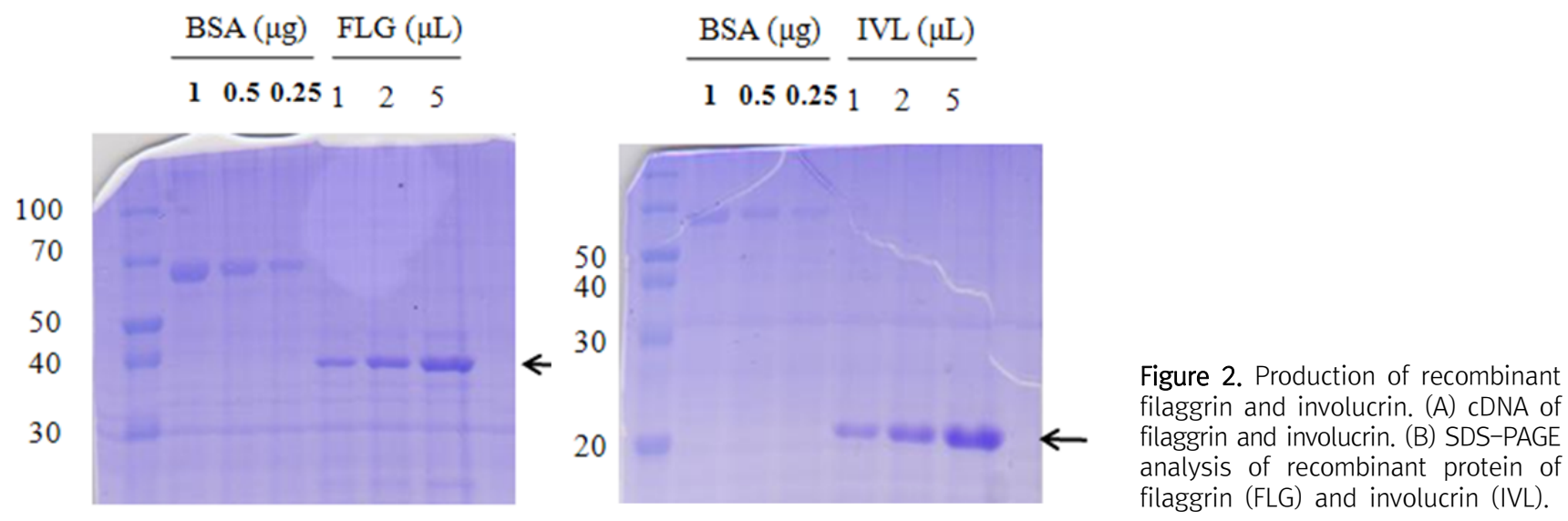

백질에 성공하였으나, 로리크린은 재조합단백질 생산이 이루 어지지 않았다(Figure 2B). 이러한 재조합단백질을 이용하여 단클론항체를 생산하였고, His 항체로 다시 확인하였다(Figure 3).

\section{3. 아토피 피부염에서의 필라그린의 변화}

Sandwich ELISA 방법을 이용하여 피부에서의 피부장벽단 백질의 발현양을 측정하였다. 정상인에 비하여 필라그린의 양 은 약 $30 \%$ 정도 감소하였고, 통계적으로 유의한 차이를 나타냈 다. 하지만, 인보루크린의 양은 필라그린에 비하여 약간 높게 나 타났으나, 정상인과 아토피 피부염 환자와의 유의한 차이를 나 타내지 않았다(Figure 4).

\section{고 찰}

아토피 피부염은 환자마다 다양한 원인으로 나타나는 치료 가 어려운 난치성 질환중의 하나이다. 본 연구에서는 아토피 피 부염의 가능성 있는 원인 중 피부장벽단백질의 발현 변화에 따 른 아토피 피부염을 진단하고, 향후 치료의 기반을 마련하고자 진행하였다.
새로운 패치개발은 인체적용에 인증기간이 오래 걸리므로, 기존에 나와 있는 화상용 피부보호로 사용하는 AriNo와 연구용 으로 가장 많이 사용되는 D-Squame을 이용하여 먼저 단백질 획득의 가능성을 확인하였고, 의외로 $\mathrm{AriNO}$ 패치에서 단백질을 얻을 수 있을 뿐만 아니라 높은 단백질 양을 얻을 수 있었다 (Figure 1). 침습적인 방법과 달리 비침습적인 방법은 유용성이 높은 편이다. 단백질 습득을 위한 본 연구와같은 Taping을 이용 한 비침습적인 방법이 시도되고 있으며, 비침습적인 방법의 중 요한 단점은 실제 진단에 적용하기 위한 채취되는 단백질의 부 족이다[8,9]. 본 연구에서는 피부장벽단백질 발현을 측정하기 위하여 피부에서 채취한 단백질을 농축하여 실시하였다. 정상 인과 아토피 피부염 환자에서 필라그린과 인보루크린 양의 측 정이 가능하였다(Figure 4). 농축 컬럼을 이용한 단백질의 측정 은 소량의 단백질 측정에 나타나는 단점을 극복할 수 있는 장점 이 있지만, 농축과정에서의 수율 및 농축 정도가 표준화되어야 만 그 측정값의 신뢰성을 얻을 수 있다. 좀 더 많은 단백질의 양 을 얻기 위하여 단백질의 채취 부위, 패치 크기, 다양한 용해액 을 사용하여 최대한 얻을 수 있는 조건을 본 연구에서는 찾을 수 있었다(Figure 1). 
A

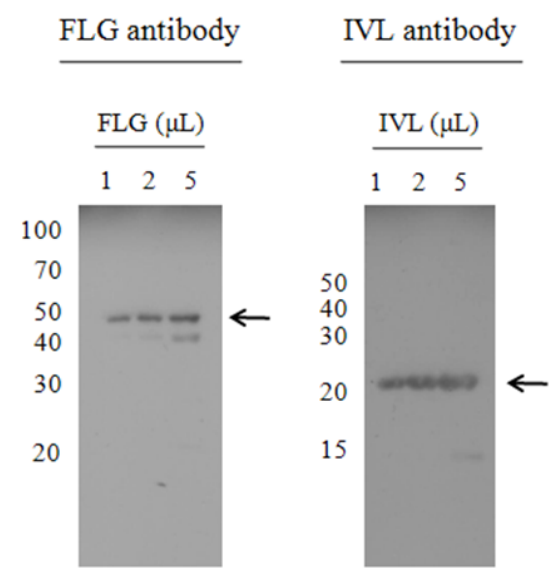

A

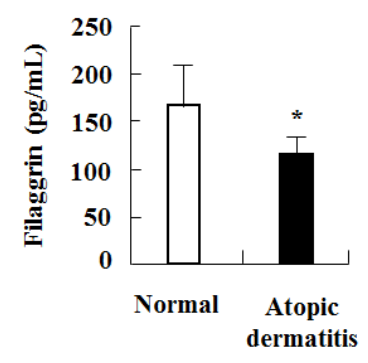

본 연구에서는 sandwich ELISA 방법이 이용되었으나, 최근 에는 이러한 단백질분석을 위한 Raman 분광광도계의 방법이 알려져 있다[10]. 향후 정확한 진단방법으로의 개발을 위해서 는 피부 단백질을 채취, 농축하는 방법, 측정방법의 표준화가 중 요한 관건이라고 할 수 있다.

피부장벽단백질의 아토피 피부염 진단 및 치료에 적용이 가 능한지 지속적인 연구가 이루어지고 있다. 본 연구에서는 발현 에 초점을 맞춰서 필라크린과 인보루크린의 발현양을 측정하여 필라그린이 유의하게 감소함을 확인하였다(Figure 4). 아토피 피부염에서의 필라그린, 인보루크린, 로리크린의 발현은 연구 마다 차이가 있어서 모두 변화가 없거나 또는 개별적으로 변화 의 차이가 나타나는 것으로 알려져 있다[11-13]. 본 연구에서는 임상환자의 수가 제한적이지만, 필라그린에서 특이적인 감소 가 나타나는 것은 주목할 만한 결과이다. 필라그린의 감소는 사 이토카인의 증가와 연관이 있다. 또한 피부장벽의 손상은 IL-3, $\mathrm{IL}-4, \mathrm{IL}-5, \mathrm{IL}-8, \mathrm{IL}-17$, IL22, TNF- $\alpha$, GM-CSF와 같은 사이 토카인의 증가를 일으켜서 상호 연결고리를 통하여 알러지 질 환에 중요한 염증반응을 일으키는 역할을 한다[14-16]. 결국 필
B

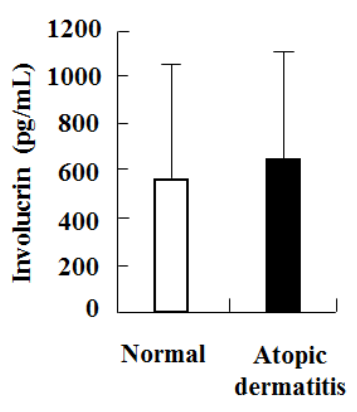

Figure 4. Filaggrin expression decreases in skin of atopic dermatitis subjects. Filaggrin (A) and involucrin (B) in skin of normal and atopic dermatitis subjects using sandwich ELISA.

라그린 감소와 사이토카인의 증가는 아토피 피부염을 더욱 더 악화시킨다. 알러지 질환에서 나타나는 사이토카인이 필라그 린의 감소를 일으키기도 한다. IL-4, IL-5, IL-13이 알려져 있으 며, TNF- $\alpha$ 와 IFN- $\gamma$ 은 mitogen-activated protein kinase (MAPK) 경로를 통하여 필라그린의 발현양을 조절한다 [17-19]. 결론적으로 아토피 피부염에서 피부장벽단백질의 발현 변화는 중요한 의의를 가지며, 비침습적인 방법을 통한 피부장벽단백 질 발현의 측정은 진단에 있어서 중요하다.

\section{요 약}

아토피 피부염은 만성염증 피부질환으로서 유전적 요소, 환 경적 요소, 면역반응의이상, 피부장벽단백질의 기능 이상에 의 하여 발생한다. 본 연구의 목적은 피부장벽단백질의 발현을 측 정할 수 있는 ELISA 키트 개발에 있다. AriNo와 D-Squame 패 치를 이용하여 비침습적으로 피부에서 단백질을 얻을 수 가 있 었고, AriNO가 좀 더 많은 단백질을 획득하였다. $0.1 \%$ Triton X-100용액이 다른 용해용액인 0.1 M Tris-HCL, $5 \mathrm{mM} \mathrm{KOH,}$ 
$0.1 \%$ Tween-20보다 높은 단백질 수율을 나타냈다. 피부장벽 단백질 측정을 위한 ELISA 키트 개발을 위하여 분자생물학적인 방법을 이용하여 필라그린과 인보루크린의 재조합단백질을 생 산하였고, 이에 대한 단일클론항체를 면역학적인 방법을 이용 하여 만들었다. 아토피 피부염 환자의 피부에서는 필리그린의 발현이 유의하게 줄어들었고, 인보루크린은 정상인과 아토피 피부염 환자에서 차이를 나타내지 않았다. 본 연구의 결과를 통 하여 아토피 피부염에서 피부장벽단백질의 중요성을 규명하였 고, 향후아토피피부염의 진단키트를 개발하는데, 유용할 것이다.

Acknowledgements: This paper was supported by Wonkwang Health Science University in 2017.

Funding: None

Conflict of interest: The authors have no financial conflicts of interest.

\section{REFERENCES}

1. Yamazaki Y, Nakamura Y, Núñez G. Role of the microbiota in skin immunity and atopic dermatitis. Allergol Int. 2017;66(4):539-544.

2. Leung DY, Bieber T. Atopic dermatitis. Lancet. 2003;361(9352): 150-160.

3. Lee NR, Lee JS, Kim IS. House dust mite allergen inhibits constitutive neutrophil apoptosis by cytokine secretion via PAR2/PKC8/p38 MAPK pathway in allergic lymphocytes. Korean J Clin Lab Sci. 2016;48(3):188-195.

4. Kim IS, Lee JS. Anti-apoptotic Effects of house dust mite, S100A8 and S100A9 on spontaneous apoptosis of neutrophils in coculture with immune cells and in the presence of T Helper cytokines. Biomed Sci Lett. 2015;21(2):122-125.

5. Kim IS, Kim MJ, Shin DH Son KH, Park HY, Lee JS. Arazyme inhibits cytokine expression and upregulates skin barrier protein expression. Mol Med Rep. 2013;8(2): 551-556.

6. Abramovits W. Atopic dermatitis. J Am Acad Dermtol. 2005; 53(1 Supple 1):86-93.

7. Liang Y, Chang C, Lu Q. The genetics and epigenetics of atopic dermatitis-filaggrin and other polymorphisms. Clin Rev Allergy
Immunol. 2016;51(3):315-328.

8. Clausen ML, Jungersted JM, Andersen PS, Slotved HC, Krogfelt KA, Agner T. Human $\beta$-defensin-2 as a marker for disease severity and skin barrier properties in atopic dermatitis. Br J Dermatol. 2013;169(3):587-593.

9. Sano Y, Masuda K, Tamagawa-Mineoka R, Matsunaka H, Murakami Y, Yamashita R, et al. Thymic stromal lymphopoietin expression is increased in the horny layer of patients with atopic dermatitis. Clin Exp Immunol. 2013;171(3):330-337.

10. Verzeaux L, Vyumvuhore R, Boudier D, Le Guillou M, Bordes S, Essendoubi M, et al. Atopic skin: In vivo Raman identification of global molecular signature, a comparative study with healthy skin. Exp Dermatol. 2017. doi: 10.1111/exd.13388 (in press)

11. Tsuji G, Hashimoto-Hachiya A, Kiyomatsu-Oda M, Takemura $\mathrm{M}$, Ohno F, Ito T et al. Aryl hydrocarbon receptor activation restores filaggrin expression via OVOL1 in atopic dermatitis. Cell Death Dis. 2017;8(7):e2931.

12. Cabanillas B, Novak N. Atopic dermatitis and filaggrin. Curr Opin Immunol. 2016;42:1-8.

13. Zaniboni MC, Samorano LP, Orfali RL, Aoki V. Skin barrier in atopic dermatitis: beyond filaggrin. An Bras Dermatol. 2016;91(4):472-478.

14. Lou H, Lu J, Choi EB, Oh MH, Jeong M, Barmettler S et al. Expression of IL-22 in the skin causes Th2-biased immunity, epidermal barrier dysfunction, and pruritus via stimulating epithelial Th2 cytokines and the GRP pathway. J Immunol. 2017;198(7):2543-2555.

15. Totsuka A, Omori-Miyake M, Kawashima M, Yagi J, Tsunemi Y. Expression of keratin 1, keratin 10, desmoglein 1 and desmocollin 1 in the epidermis: possible downregulation by interleukin-4 and interleukin-13 in atopic dermatitis. Eur J Dermatol. 2017;27(3):247-253.

16. Floudas A, Saunders SP, Moran T, Schwartz C, Hams E, Fitzgerald DC et al. IL-17 receptor A maintains and protects the skin barrier to prevent allergic skin inflammation. J Immunol. 2017;199(2):707-717.

17. Chang L, Karin M. Mammalian MAP Kinase signaling cascades. Nature. 2001;410(6824):33-40.

18. Lin A. Activation of the JNK signaling pathway: breaking the brake on apoptosis, Bioessays 2003;25(1):17-24.

19. Lee JS, Kim IS. Suppressive effect of arazyme on neutrophil apoptosis in normal and allergic subjects. Suppressive effect of arazyme on neutrophil apoptosis in normal and allergic subjects. Biomed Sci Lett. 2014;20(4):244-249. 